\title{
MODEL BELAJAR KELOMPOK TERHADAP PRESTASI BELAJAR IPA UNTUK SISWA SEKOLAH DASAR TAHUN PELAJARAN 2017/2018
}

\author{
M. Zainal Mustamiin \\ Program Studi Bimbingan dan Konseling, FIPP UNDIKMA \\ Email:mzainalmustamiin@gmail.com
}

\begin{abstract}
Abstrak: Cara yang dapat dilakukan untuk mengatasi masalah dalam dunia belajar mengajar adalah dengan menerapkan model kelompok belajar kompetitif dalam belajar IPA. Ide utama model kelompok belajar kompetitif adalah siswa berdiskusi dalam kelompok kecil dalam suatu kelas yang terdiri dari beberapa kelompok, diberikan kesempatan untuk berpartisipasi aktif dalam aktivitas belajar. Untuk mencapai tujuan tersebut maka salah satunya yang kiranya perlu menjadi pencermatan adalah bagaimana usaha guru untuk meningkatkan proses pembelajaran IPA. Jenis penelitian yang digunakan dalam penelitian ini adalah deskriptif kualitatif. Berdasarkan hasil penelitian yang diperoleh, dapat disimpulkan bahwa Penerapan model belajar kelompok dapat meningkatkan prestasi belajar siswa pada pokok bahasan Kenampakan Alam dan Buatan di Indonesia pada Mata Pelajaran IPA untuk sekolah Dasar Tahun Pelajaran 2017/2018. Hal ini dibuktikan dengan: adanya peningkatan hasil belajar siswa yakni pada data awal sebelum Penerapan model belajar kelompok di terapkan hasil belajar siswa mencapai $62,5 \%$. Kemudian pada Siklus I meningkat menjadi $66,66 \%$ dan pada Siklus II meningkat menjadi $87,5 \%$ secara klasikal dinyatakan tuntas.
\end{abstract}

Kata Kunci: Belajar Kelompok, Prestasi Belajar

\section{Latar Belakang}

Upaya pemerintah dalam meningkatkan mutu pendidikan terus dilakukan agar diperoleh lulusan yang berkualitas, sesuai dengan kebutuhan masyarakat dan tuntutan kerja saat ini. Upaya-upaya pemerintah tersebut meliputi penyediaan sarana dan prasarana penunjang pendidikan, perubahan kurikulum, sampai dan prasarana penunjang pendidikan, perubahan kuarikulum, sampai dengan penataran guru-guru tentang pembaharuan model pembelajaran yang digunakan dalam kegiatan pembelajaran. Model pembelajaran yang dimaksud adalah model. Mengajar, inilah kata kunci yang sangat mempengaruhi keberhasilan sebuah proses pendidikan, dan mengajar pulalah yang mendapat kritik keras dari Paulo Preire dengan model pembelajaran pasif, yakni guru menerangkan, murid mendengarkan, guru mendiktekan, murid mencatat, guru bertanya, murid menjawab, dan seterusnya. Model seperti ini merpakan salah satu bentuk penindasan terhadap siswa, karena menghambat kreatifitas dan pengembangan potensi mereka, Rosyada (2004).

Keadaan seperti di atas, juga terjadi sekolah dasar dan kelas lainnya, akibat dari kurang efektifnya proses pembelajaran sebagian besar siswa mendapatkan nilai yang kurang memuaskan yakni 51\% siswa belum mencapai standar nilai KKM. Keadaan seperti ini sebenarnya bisa di atasi, apabila guru bisa menerapkan inovasi model mengajar yanga menarik dan melibatkan semua siswa untuk berpartisipasi aktif dalam proses pembelajaran yang berlangsung, sehingga nantinya mereka akan mengikuti setiap proses dengan baik.

Dalam aplikasinya untuk mencapai tujuan IPA seperti yang telah dirumuskan, bahwa sebagai ukuran nyata adalah hasil belajar peserta didik. Untuk mencapai tujuan tersebut maka salah satunya yang kiranya perlu menjadi pencermatan adalah bagaimana usaha guru untuk meningkatkan proses seperti yang telah dijelaskan diatas, sehingga dalam kesempatan ini penulis sangat tertarik dengan salah satu metode pembelajaran yang memungkinkan bisa diterapkan dalam pembelajaran IPA.

Jadi, dengan penerapan model ini, diharapkan aktifitas siswa pada saat proses belajar-mengajar minimal kategori aktif, dan prestasi belajar siswa meningkat, sehingga tidak ada lagi siswa yang malas, tidak senang belajar, mengantuk, dan kegiatan lain yang tidak diharapkan dalam kegiatan belajar mengajar.

Bertolak dari permasalahan dan hasil penelitian tersebut diatas serta dirasa perlu untuk lebih mengembangkan penelitian- 
penelitian yang telah ada, maka penulis tertarik dan merasa perlu untuk mengadakan penelitian, dengan judul "Model Belajar Kelompok Terhadap Prestasi Belajar IPA untuk sekolah Dasar Tahun Pelajaran 2017/2018”.

\section{KAJIAN PUSTAKA}

\section{Model Belajar Kelompok}

Belajar kelompok kompetitif terdiri dari dua istilah yaitu belajar kelompok dan kompetitif. Belajar kelompok adalah belajar yang dilakukan secara berkelompok yang terdiri dari beberapa orang siswa atau individu. Model belajar kelompok atau bekerja dalam situasi kelompok, mengandung pengertian bahwa siswa dalam satu kelompok dipandang sebagai satu kesatuan (kelompok) Sagala, (2008). Sedangkan kompetitif dari kata kompetensi yang artinya persaingan untuk merebut kemenangan (Kamus Besar Bahasa Indonesia). Jadi, dari pengertian tersebut dapat disimpulkan bahwa belajar kelompok kompetitif adalah belajar yang dilakukan secara berkelompok dalam suasana persaingan untuk merebut kemenangan.

Kompetitif dapat digunakan sebagai alat motivasi untuk mendorong siswa agar bergairah belajar, baik dalam bentuk individu maupun kelompok dalam pendidikan Jamarah, (1994). Kondisi ini bisa dimanfaatkan untuk menjadikan proses interaksi belajar-mengajar yagn kondusif. Untuk menciptakan suasana yang demikian, metode mengajar memegang peranan. Guru bisa membentuk siswa ke dalam beberapa kelompok belajar di dalam kelas, ketika pelajaran sedang berlangsung. Semua siswa dilibatkan ke dalam suasana. Guru bertindak sebagai fasilitator, sementara siswa aktif belajar sebagai subyek yang memiliki tujuan.

Secara positif, model belajar kelompok kompetitif dapat menimbulkan rasa cemas yang justru memacu siswa atau kelompok untuk meningkatkan kegiatan belajar mereka sehingga prestasi belajar mereka meningkat. Utuk bisa berhasil dalam model belajar kelompok yang lain. Salah satu palsafah yang mendasari semangat kompetitif (kompetisi) adalah teori evolusi Darwin. Teori ini mengatakan bahwa siapa yang kuat adalah siapa yang menang dan bertahan dalam kehidupan. Dengan kata lain makhluk termasuk manusia harus bisa berjuang memenangkan persaingan dengan makhluk hidup lainnya dan merebut sumber daya hidup yang biasanya tersedia secara terbatas.

\section{Prestasi Belajar}

Prestasi belajar adalah sebuah kata yang terdiri dari dua kata, yakni "prestasi" dan "belajar". Diantara keduanya memiliki arti yang berbeda. Oleh karena itu untuk lebih memudahkan dan memahami lebih mendalam tentang pengertian "prestasi belajar", maka terlebih dahulu sebaiknya diketahui makna kata "prestasi" dan "belajar".

"Prestasi" adalah hasil dari suatu kegiatan yang telah dikerjakan, diciptakan, baik secara individual maupun secara kelompok. (Djamarah, 1991 :19). Prestasi tidak pernah dihasilkan selama seseorang tidak melakukan kegiatan. Dari kegiatan yang digeluti untuk mendapatkan prestasi, maka muncul berbagai pendapat dari para ahli sesuai keahliannya memberikan pengertian mengenai kata "prestasi". Namun secara umum para ahli sepakat, bahwa "prestasi" adalah "hasil" dari suatu kegiatan.

\section{Pembelajaran IPA}

Pembelajaran IPA adalah ilmu pengetahuan yang sifatnya sistematis dan berlaku secara umum atau universal ,yang membahas tentang sekumpulan data mengenai gejala alam yang dihasilkan yang dihasilkan dengan berdasar pada hasil observasi ,eksperimen ,penyimpulan dan penyusunan teori.

Istilah ilmu pengetahuan alam ini dikenal juga dengan istilah yaitusains . kata sains itu sendiri berasal dari bahasa latin yaitu scientia . yang secara harfiah artinya pengetahuan tetapi dalam perkembanganya menjadi khusus Ilmu Pegetahuan Alam atau Sains. Ilmu pengetahuan ala mini berhubungan dengan cara mencari tahu tentang alam yang sistematis .sehingga IPA bukan hanya penguasaan kumpulan 
pngetahuan yang berupa fakta saja konsep dan prinsipnya, tetapi juga merupakan suatu proses dalam sebuah penemuan. Sehingga pada hakikatnya IPA adalah sebuah ilmu untuk mencari tahu memahami alam semesta dengan cara yang sistematik, serta mengembngkan pemahaman ilmu pengetahuan mengenai gejala alam yang dituangkan dalam fakta ,konsep ,prinsip,pada hukum yang teruji kebenaranya. Sehingga dalam mendapatkan pengetahuan harus melalui suatu rangkaian kegiatan didalam sebuah metode ilmiah, dan menuntut sikap yang ilmiah .

\section{METODE PENELITIAN}

Jenis penelitian yang digunakan dalam penelitian ini adalah deskriptif kualitatif. Penelitian ini jika dilihat dari segi tempat penelitian, maka termasuk dalam penelitian lapangan (field research). Penelitian lapangan adalah penelitian yang berusaha melakukan studi terhadap realitas kehidupan sosial masyarakat secara langsung. Menurut Kirk dan Miller seperti yang dikutip oleh Lexy J. Moleong dalam bukunya yang berjudul Metodologi Penelitian Kualitatif, penelitian kualitatif menurutnya adalah tradisi tertentu dalam ilmu pengetahuan sosial yang secara fundamental bergantung pada pengamatan manusia dalam kawasannya sendiri dan berhubungan dengan orang-orang tersebut dalam basanya peristilahannya. (Moleong Lexy J 2005). Penelitian kualitatif adalah penelitian yang dimaksudkan untuk mengungkap gejala secara holistickontekstual (secara menyeluruh dan sesuai dengan konteks/ apa adanya) melelui pengumpulan data dari latar alami sebagai sumber langsung dengan instrument kunci penelitian itu sendiri.

Penulis menggunakan pendekatan kualitatif yang didasari atas beberapa alasan. Pertama, yang dikaji adalah makna dari suatu tindakan atau apa yang berada dibalik tindakan seseorang. Kedua, di dalam menghadapi lingkungan sosial, individu memiliki strategi bertindak yang tepat bagi dirinya sendiri, sehingga memerlukan pengkajian yang mendalam. Penelitian kualitatif memberikan peluang bagi pengkajian mendalam terhadap suatu fenomena. Ketiga, penelitian tentang keyakinan, kesadaran dan tindakan individu di dalam masyarakat sangat memungkinkan menggunakan penelitian kualitatif karena yang dikaji adalah fenomena yang tidak bersifat eksternal dan berada di dalam masing-masing individu.

Keempat, penelitian kualitatif memberikan peluang untuk meneliti fenomena secara holistik. Fenomena yang dikaji merupakan suatu kesatuan yang tak terpisah karena tindakan yang terjadi di kalangan masyarakat bukanlah tindakan yang diakibatkanyang diakibatkan oleh satu dua faktor akan tetapi adalah melibatkan sekian banyak faktor yang saling terkait.

\section{Instrumen Penelitian}

Arikunto (2002) menerangkan bahwa instrument penelitian adalah alat/fasilitas yang digunakan oleh peneliti dalam mengumpulkan data agar pekerjaan lebih mudah dan hasilnya lebih baik, dalam artian lebih cermat, lengkap dan sistematis sehingga lebih mudah diolah. Adapun instrument penelitian yang digunakan dalam penelitian ini adalah:

1) Lembar observasi kegiatan pembelajaran dalam mata pelajaran IPA

2) Tes hasil belajar berupa soal essay untuk mengukur kemampuan siswa dalam pelajaran IPA.

\section{HASIL PENELITIAN DAN}

\section{PEMBAHASAN}

\section{Hasil Penelitian}

Penelitian Tindakan Kelas ini dilakukan untuk meningkatkan prestasi belajar siswa khususnya pada pokok bahasan tentang Kenampakan Alam Dan Buatan di Indonesia dengan menggunakan Model belajar kelompok pada siswa sekolah dasar .

Data Hasil Observasi Aktivitas Belajar Siswa

Ringkasan dari hasil observasi aktivitas siswa pada Siklus I ini dapat dilihat pada tabel berikut 
Keterangan pemberian skor "setiap 1 (satu) indikator nampak nilainya 1 (satu)".

\begin{tabular}{|c|c|c|}
\hline Skala perolehan & Persentase (\%) & Kategori \\
\hline $15-20$ & $75-100$ & Sangat aktif \\
\hline $10-15$ & $50-75$ & Aktif \\
\hline $5-10$ & $25-50$ & Cukup aktif \\
\hline $0-5$ & $0-25$ & Tidak aktif \\
\hline
\end{tabular}

Data lengkap tentang aktivitas belajar siswa selama proses pembelajaran pada Siklus I ini dapat dilihat pada (lampiran 03) berdasarkan hasil observasi dua kali pertemuan diperoleh jumlah skor total aktivitas Siswa Kelas IV adalah 9 skor untuk 5 indikator yang tampak pada pertemuan ke 1 dan skor 11 untuk pertemuan ke 2 sehingga jumlah rata-rata skor adalah $(9+11): 2=10$.
Berdasarkan kriteria pengelolaan aktivitas siswa yang telah ditetapkan, maka diperoleh skor aktivitas belajar siswa untuk setiap aktivitas dalam pembelajaran Siklus I tergolong cukup aktif (lampiran 03).

\section{Data Hasil Observasi Aktivitas Guru}

Ringkasan dari hasil observasi aktivitas guru pada Siklus I ini dapat dilihat pada tabel berikut

Keterangan pemberian skor "setiap 1 (satu) indikator nampak nilainya 1 (satu)".

\begin{tabular}{|c|c|c|}
\hline Skala perolehan & Persentase $(\%)$ & Kategori \\
\hline $15-20$ & $75-100$ & Sangat aktif \\
\hline $10-15$ & $50-75$ & Aktif \\
\hline $5-10$ & $25-50$ & Cukup aktif \\
\hline $0-5$ & $0-25$ & Tidak aktif \\
\hline
\end{tabular}

Data lengkap tentang aktivitas guru selama proses pembelajaran pada Siklus I ini dapat dilihat pada (lampiran 04) berdasarkan hasil observasi dua kali pertemuan diperoleh jumlah skor total aktivitas guru Kelas IV adalah 13 skor untuk 5 indikator yang tampak pada pertemuan ke 1 dan skor 15 untuk pertemuan ke 2 sehingga jumlah rata-rata skor adalah $(13+15): 2=14$.

Berdasarkan kriteria pengelolaan aktivitas guru yang telah ditetapkan, maka diperoleh skor aktivitas belajar guru untuk setiap indikator dalam pembelajaran Siklus I tergolong baik (lampiran 04).

\section{Data Hasil belajar Siswa}

Ringkasan data hasil prestasi belajar siswa pada Siklus I dapat dilihat pada tabel berikut.

Data Hasil Observasi Aktivitas Guru
Data lengkap tentang aktivitas guru selama proses pembelajaran pada Siklus II ini dapat dilihat pada (lampiran 07) berdasarkan hasil observasi dua kali pertemuan diperoleh jumlah skor total aktivitas guru Kelas IV adalah 15 skor untuk 5 indikator yang tampak pada pertemuan ke 1 dan skor 18 untuk pertemuan ke 2 sehingga jumlah rata-rata skor adalah $(15+18): 2=16,5$.

Berdasarkan kriteria pengelolaan aktivitas guru yang telah ditetapkan, maka diperoleh skor aktivitas belajar guru untuk setiap indikator dalam pembelajaran Siklus II tergolong Sangat baik.

\section{Pembahasan}

Dapat terlihat di atas bahwa Siklus I menunjukkan bahwa jumlah Nilai rata-rata hasil belajar IPA pada siklus I adalah 62,08 dengan ketuntasan klasikal sebesar 66,66 \% 
dimana dari 24 siswa yang tuntas 16 orang siswa dan yg tidak tuntas 8 orang siswa. Sedangkan pada siklus II rata-rata nilai hasil belajar IPA siswa adalah $72,70 \%$ dengan ketuntasan klasikal 87,5 \%. Dimana siswa yang tuntas sebanyak 21 siswa dan yang tidak tuntas 3 orang siswa, Sehingga terjadi peningkatan nilai rata-rata dari 62,08 disiklus I menjadi 72,70 disiklus II. Dan ketuntasan klasikal disiklus I 66,66\% menjadi 87,5 \% di siklus II.

Bertitik tolak pada kekurangankekurangan yang terdapat pada Siklus I, maka pada Siklus II Guru dan peserta didik telah melakukan perbaikan-perbaikan pada proses kegiatan belajar mengajar sesuai dengan skenario pembelajaran pada Siklus II, dan pada Siklus II menunjukkan adanya perubahan atau peningkatan presasi belajar. Data hasil evaluasi/tes pada Siklus II diperoleh presentasi ketercapaian ketuntasan klasikal yaitu $87,5 \%$ artinDya jumlah anak yang memperoleh nilai $60 \mathrm{ke}$ atas adalah $87,5 \%$, dari jumlah anak keseluruhan . Jadi terdapat peningkatan yaitu dari $66,66 \%$ menjadi $87,5 \%$.

Karena dari semua siswa semuanya telah mencapai nilai sama dan lebih dari 60 maka pada Siklus II ini dinyatakan tuntas dan penelitian ini dihentikan. Dari data hasil analisis evaluasi pada Siklus II, maka dapat disimpulkan bahwa pembelajaran melalui Penerapan model belajar kelompok terbukti dapat meningkatkan prestasi belajar siswa terhadap materi pokok bahasan kenampakan alam dan buatan di Indonesia.

\section{KESIMPULAN}

Berdasarkan hasil penelitian yang diperoleh, dapat disimpulkan bahwa
Penerapan model belajar kelompok dapat meningkatkan prestasi belajar siswa pada pokok bahasan Kenampakan Alam dan Buatan di Indonesia pada Mata Pelajaran IPA Untuk Sekolah Dasar. Hal ini dibuktikan dengan: adanya peningkatan hasil belajar siswa yakni pada data awal sebelum Penerapan model belajar kelompokdi terapkan hasil belajar siswa mencapai $62,5 \%$. Kemudian pada Siklus I meningkat menjadi $66,66 \%$ dan pada Siklus II meningkat menjadi $87,5 \%$ secara klasikal dinyatakan tuntas.

\section{DAFTAR PUSTAKA}

Abdurrahman, Mulyanto, 2003, Pendidikan bagi Anak Berkesulitan Belajar: Jakarta: Penerbit Rineka Cipta.

Arikunto, Suharsini, 2001. Dasar-dasar Evaluasi Pendidikan. Jakarta: Penerbit Bina Aksara.

Arikunto Suharsimi. 2006. Prosedur Penelitian. Jakarta: Rineka Cipta.

Asnawir, H. Dasn M. Basyiruddin Usman, 2002. Media Pembelajaran. Jakarta: Ciputat Pers.

Djamarah Syaiful Bahri, 2002. Psikologi Belajar. Jakarta. Rineka Cipta

Isjoni. 2007. Cooperative Learning Efektifitas Pembelajaran Kelompok. Bandung. Alfabeta

Muhibbin Syah, 2009. Psikologi belajar. Jakarta : Raja Grafindo Persada.

Nurkencana, 1990. Evaluasi Hasil Belajar. Surabaya.: Usaha Nasional.

Nurkhalis. 2006. SAINS 4 Untuk Kelas 4 SD. Jakarta: Media Pustaka.

Samatowa, A. 2009. Progresif Ilmu Pengetahuan Alam. Penerbit PT. Pustaka Manggala. 